e-ISSN: 2550-1313 | p-ISSN: 2087-9849

http://jurnal.fkip.unila.ac.id/index.php/jpp/

\title{
The Principal Management in Implementing Islamic School Culture at SMAN Unggul Tunas Bangsa, Southwest Aceh
}

\author{
Arisman Juanda $^{1 *}$, Yusrizal ${ }^{2}$, Nasir Usman ${ }^{2}$ \\ ${ }^{1}$ Master of Education Administration, Universitas Syiah Kuala, Indonesia. \\ ${ }^{2}$ Universitas Syiah Kuala, Indonesia. \\ *Corresponding email: arisman.juanda@yahoo.com
}

Received: 19 April 2021

Accepted: 29 July 2021

Published: 29 August 2021

Abstract: The purpose of this research is to understand the plan, implementation, supervision and evaluationin implementing Islamic school culture. This research uses descriptive method with qualitative approach. Data collection were conducted through interviews, observations, and documentation studies. The subjects of this research are principal, religion teacher, homeroom teacher of grade X, XI, XII, and president of student council as student representative. The results of this research shows islamic school cultural planning is planned in school meetings, special programs concerning religious events, clean Friday group schedules, homeroom notes, making rewards and punishments. Implementation by providing motivation to students, support, commitment and cooperation in school equipment so that it can be implemented properly. Supervision is carried out jointly such as the existence of representatives of principals who help, teachers, homeroom teachers and this supervision is carried out every day. The results of the evaluation carried out showed that there was a development of students' awareness in carrying out Islamic culture in schools, and also that there were still violating students who had not fully implemented this Islamic school culture.

Keywords: principal management, culture, islamic school.

Abstrak: Tujuan dari penelitian ini adalah untuk mengetahui perencanaan, pelaksanaan, supervisi dan evaluasi dalam penerapan budaya madrasah. Penelitian ini menggunakan metode deskriptif dengan pendekatan kualitatif. Pengumpulan data dilakukan melalui wawancara, observasi, dan studi dokumentasi. Subyek penelitian ini adalah kepala sekolah, guru agama, wali kelas X, XI, XII, dan ketua OSIS sebagai perwakilan siswa. Hasil penelitian ini menunjukkan perencanaan budaya madrasah direncanakan dalam pertemuan sekolah, program khusus tentang acara keagamaan, jadwal kelompok Jumat bersih, catatan wali kelas, membuat hadiah dan hukuman. Pelaksanaannya dengan memberikan motivasi kepada siswa, dukungan, komitmen dan kerjasama dalam peralatan sekolah sehingga dapat dilaksanakan dengan baik. Pengawasan dilakukan secara bersama-sama seperti adanya wakil kepala sekolah yang membantu, guru, wali kelas dan pengawasan ini dilakukan setiap hari. Hasil evaluasi yang dilakukan menunjukkan bahwa ada perkembangan kesadaran siswa dalam menjalankan budaya Islam di sekolah, dan juga masih ada siswa yang melanggar yang belum sepenuhnya menerapkan budaya sekolah Islam ini.

Kata kunci: menejemen kepala sekolah, budaya, sekolah islam.

\section{To cite this article:}

Juanda, A., Yusrizal, \& Usman, N. (2021). The Principal Management in Implementing Islamic School Culture at SMAN Unggul Tunas Bangsa, Southwest Aceh. Jurnal Pendidikan Progresif, 11(2), 456463. doi: 10.23960/jpp.v11.i2.202126. 


\section{- INTRODUCTION}

Education is one very important factor in human life, both as individuals and as being a social creature, because education is a process of personal formation someone who can cultivate their potential. Therefore, everyone should get an education even if he is already an adult. Education can be obtained either in school or outside of school are important education is useful for each individual (Zuilkowski, Piper, Ong'ele, \& Kiminza, 2018; Griffith et.al., 2017; Meyers \& Hambrick, 2017).

Education is an effort in order to achieve the purpose of life for humans to happiness in this world and hereafter. Education is unlikely to materialize in a person without the continuous efforts dibaringi all time with efforts to pass on the values which is very valuable from a further captivate the generations that. Education is a process of transformation of culture from one generation to another, the process of personality formation, the process of forming students to become good citizens, as well as preparation of labor so that the output of the education world can live well in society. The success of educational organizations in shaping and managing the Islamic culture can not be separated from the management of the principal's leadership in organizing the entire potential of the existing school. Principal as a leader in forming and managing Islamic culture has responsibility for all aspects of education ranging from responsibility for the learning process in the classroom to organize environmental education unit. Based on the results of documentation studies at leading schools on KTSP Book I, Syllabus and RPP teachers and interviews with five superior school principals it was found that there was an Islamic cultural substance in the curriculum structure and development developed by the school. Principals who play a role as a leader in forming and managing Islamic culture should be done with the maximum that is responsible and sustainable.
Starting from the concept of planning, implementation, monitoring until the evaluation of various Islamic activities in the school, as well as SMA Superior Tunas Bangsa Southwest Aceh Islamic culture would have to run the school

\section{FOUNDATION THEORY}

Management is derived from the word to manage the means set. The setting is done through the process and are governed by the order of the management functions. Because management is defined set then raised a few questions for us like those mentioned, why should be organized, who organize, how to set it up, and which should be regulated. Management is a discipline that is tasked with finding the truth in the title of theoretical and methodological dimension that must be tested and proved by facts / data objectively verified. Therefore management as essential science to be developed in order to get the truth of science (Kairys, 2018; Anderson, Ellwood, \& Coleman, 2017; Dandan, \& Marques, 2017).

In the management are management functions that can be used as a benchmark in coordinating an organization that can serve as the basis to regulate the management itself society (Bush, Bell, \& Middlewood, 2019; Chan, 2018; Baharudin, 2017; Cajiao, \& Burke, 2016). There are four management functions. Planning is the process defined organizational goals and how to achieve those goals. Planning is one of the main functions of management (Adams, Olsen, \& Ware, 2017; Kempa, Ulorlo, \& Wenno, 2017; Yieng, \& Daud, 2017). Planning is the process of defining the goals of the organization, and then presents clearly the strategies, tactics, and operations necessary to achieve that goal. Planning is an attitude in making multiple or single targets to be achieved for the future. In the organization's efforts to plan the action in thinking about the direction, goals and actions to be taken to achieve the agreed goals Along with seeing a 
variety of resources and methods / techniques are appropriate (Ololube, 2017; Mohammed, 2016).

Categorize and define various important activities and provide power to implement. It can be understood that organitation is a collection of some of the people into a group that will determine the implementation of each activity (Jamli, 2019; Bairaðauskienë, 2017; Böhlmark, Grönqvist, \& Vlachos, 2016). Actuating means to move people to want to work with full awareness of itself or together to achieve the desired aim. Above understanding can be understood that the actuating is seeking individuals to have awareness of the work in accordance with the objectives to be obtained.

Supervision is the act of a manager to control and to control the course of events that lead her in order to achieve the goals set. Controlling or supervisory often referred to as the control of conducting monitoring and correlation so that subordinates can do its job properly according to the original task. From this can be explained that the surveillance is an act of a manager in controlling and monitoring the course of a task carried out by subordinates so that it can be done properly (Serdyukov, 2017; Wong, \& Daud, 2017).

After supervising the other important aspects that must be considered in managing aorganinasi is by doing the evaluation. Evaluation is the measurement and comparison of the results to be achieved. Evaluating a function before taking corrective action by management. This function is carried out if the organization there are things that must be evaluated.

School is an institution that is both complex and its contained with in the dimensions of each other. The school has a leader who is called by the school principal. The principal is a person who was given the responsibility to lead a school. School principals play an important role as a central force that became the driving force of school life and should understand their duties and functions for the success of the school and have a concern to staff and students. School leadership is the ability of a functional staff of teachers assigned to lead a school to mobilize all the resources available to a school so that it can usefully be put maximum effort to achieve the goals set.

Professionalism principals can be reached if a principal has and understands the principles of an educational leader. Based on the Regulation of the Minister of National Education (Permendiknas) No. 13 Year 2007 The principal is a teacher who has the additional task to develop and lead its members to achieve the goal of" As the leader of the formal institutions Principals must necessarily be a good educator for. Where educators as a motivator, facilitator, and a dynamic in the learning process will deliver learners to learn independently continuously (long life study). Culture is the result of life experiences, habits and selection process (accept or reject) the norms that exist in the way of her social interaction or put himself in the middle of a particular environment.

The concept of culture can from two sides. The first culture comes from the spirit and value of quality of life, two of the manifestations of his performance in a way to feel or observe the rules and procedures governing. From the description above cultural experts are beliefs and values that bind from habits against the existing norms or rules, then the culture is also based on the spirit of life that can be felt.

The first culture comes from the spirit and value of quality of life, two of the manifestations of his performance in a way to feel or observe the rules and procedures governing. From the description above cultural experts are beliefs and values that bind from habits against the existing norms or rules, then the culture is also based on the spirit of life that can be felt. The first culture comes from the spirit and value of quality of life, 
two of the manifestations of his performance in a way to feel or observe the rules and procedures governing. From the description above cultural experts are beliefs and values that bind from habits against the existing norms or rules, then the culture is also based on the spirit of life that can be felt.

Islamic school culture is a unique culture that developed in educational practice by schools that Islam breath. In this regard, an Islamic school culture can improve the quality of school life can be portrayed in the attitude, behavior of students as honest, trustworthy embarrassment, err, bold menegaki truth, clean, polite, peaceful. In this case the top schools in Aceh may reflect how, effort, and commitment inherent in the people, especially school principals, teachers, and educational staff in defining the value of Islam into the value system and the process of the work. The transformation of value on a person's personality system which will form the patterns of thought in view of the meaning of reality experience. This value can be sourced from various aspects of both religions, cultures, social norms and others. Islamic values that are expected to exist in schools and implanted on students is such an honest, trustworthy, shy err, dare to uphold the truth, clean, disciplined, courteous, polite, love peace, and its other commendable character which is a pattern of life of a Muslim.

\section{METHODS}

In this study the authors used a qualitative approach (qualitative Research) as the basis for discussion of the results. The method of qualitative research is a research method based on the philosophies of positivism, is used to examine the condition of natural objects. The qualitative research is a research approach that revealed certain social situations to describe reality correctly, formed by words based on techniques of data collection and analysis of relevant data obtained from the situation which scientific.
Locations in conducting this study contained in SMA Tunas Bangsa Pre-Eminent State Senior High School of Aceh Barat Daya which is within the region of Southwest Aceh district government. The subject of this research is the principal, teachers of religion, homeroom, and Osis representatives SMA Tunas Bangsa Pre-Eminent State Senior High School of Aceh Barat Daya numbering.

In the assessment of research instruments using observation, interview and documentation study, In qualitative research, data analysis performed at the time of data collection takes place, and after the completion of data collection in a particular period. Analyzing the data and information obtained from baseline to end of study with reference to the theoretical basis related to the problem under study is concerned with the management of the principal in the implementation of school culture Islamic analysis in qualitative research was conducted by characterizing, directing, organizing (reduction), summarizes important stale and draw conclusions (verification) from the research results obtained in the field.

\section{RESULTS AND DISCUSSION}

\section{Planning Implementation Principal in the Islamic School Culture in SMA Tunas Bangsa Pre-Eminent State Senior High School Of Aceh Barat Daya}

The results showed that there is a culture of planning implement Islamic school in SMA Tunas Bangsa Pre-Eminent State Senior High School Of Aceh Barat Daya Southwest Aceh. Planning application program that supports the Islamic school culture by holding a coordination meeting of the school, the specific program concerned with religious events, schedule for Friday perkelompokan clean sheet record homeroom, their reward and punishmen for the menjankan and do not run it. The coordination meeting first held with the school, to be able to 
pour a variety of ideas, ideas, opinions, which is expected to not be separated from the vision and mission of the school and also the desire or aspiration of the principal / head who want to implement a school culture islami in educational institutions, The coordination meeting which made aiming to clarify the school steps in implementing the Islamic school culture.

Implementation of the planned Islamic school culture are concerned with moral guidance for learners that includes prayer congregation, discipline, clean, honest, shake culture, commemorating PHBI, pray when it comes and from school for boys and girls, and others. Based on the study of documentation on excellent schools to books I SBC, syllabus and lesson plans of teachers and interviews with school principals featured five known that there are substances in the structure of Islamic culture and development curriculum developed school.

The essence of planning is an attempt to formulate what is actually to be achieved by an organization or school and how you want to achieve something that can be realized through a series of formulation of a specific.

\section{Application and Implementation of Islamic} School Culture in SMA Tunas Bangsa PreEminent State Senior High School Of Aceh

\section{Barat Daya}

Implementation of the application of Islamic school culture necessarily involve a variety of devices other schools to support this Islamic school cultural program started the new academic year and will be continued in the next year. Efforts in the implementation of principals, viceprincipals, teachers of the motivation the students, providing both moral and material support, commitment and cooperation with all the school is emphasized so that it can be done well. The whole device is the school board of teachers, homeroom, staff, TU, committees, and parents of students in this highly influential to the smooth running of schools diingin goal is achieved as shake culture, pray before and after study, prayer congregation at school, Kultum after prayers, boarding lightning, discipline / attendance on time, Friday was clean and so on. If there are barriers to the coordination meeting will be held at the beginning and end of the month to find a solution. If it does not happen to be reprogrammed in the next month and in other activities. School culture is the dominant values are supported by the school or philosophy that guides school policy / madrasah to all the elements and components of the school including educational stakeholders, such as how to carry out the work at the school as well as the assumptions or basic belief held by Islamic school. Culture personnel is the norm life that comes from Islamic law. This culture is an essential infrastructure to be managed in the framework of the implementation of value-based teaching in schools, particularly schools that characterized Islam. Islamic culture to be reflected in the attitude: Tabassum (smile), cherish time, love science, mujahadah (hard work and optimal), tanafus and ta' awun (competing and mutual help).

\section{Supervision of the application of Islamic school culture in SMA Tunas Bangsa Pre- Eminent State Senior High School Of Aceh Barat Daya}

Based on information obtained surveillance carried out together as their representatives assist school heads, teachers, homeroom and supervision is done every day. The purpose of supervision by school devices to be able to determine the appropriate steps when it evaluates, and it can diperjelaskan back when the school held a coordination meeting held once a month.

Supervision as the process of setting various factors of a company to comply with ketepanketepan in the plan.In this case the effort to control the implementation of Islamic culture is one that 
can support the evaluation to be done whether or not the indicators of school culture can be known. This can be done on a regular basis and gradually the short term, medium and long term.

\section{Application Evaluation Culture Islamic school in SMA Tunas Bangsa Pre-Eminent State Senior High School Of Aceh Barat Daya}

Evaluationdone by making Coordination Meeting Monthly and semi-annual, evaluation done a good meneyeluruh if that is not well maintained revised. resultevaluation of the development of students' awareness gained in running the school of Islamic culture, and also obtained the persistence of students who violate and not yet fully implementing an Islamic school culture. In this case will give rewards to the commitment to run, and also provide punishmen for non-compliance with the regulations that have been made. This evaluation involves the whole school devicesespecially as it concerns the teacher with the personality value.

The purpose of evaluating the culture and the school environment, namely: (1) determine the achievement of the set targets, (2) determine targets that have and have not been reached, (3) to identify factors inhibiting the achievement of the target, (4) to know the efforts that have been made in order to overcome obstacles, (5) identify elements of the plan and the implementation of programs that need to be improved and developed in order to obtain a more optimal result for the time to come.

\section{CONCLUSIONS}

Planning principals in the application of Islamic schools in high school culture SMATunas Bangsa Pre-Eminent State Senior High School Of Aceh Barat Daya with held a coordination meeting of the school, the specific program concerned with religious events, schedule for Friday perkelompokan clean sheet record homeroom, their reward and punishmen for the menjankan and not runningit is also the presence of the document 1 is the first step taken by the school for further use in the learning process, from student attendance to school, until the students return home. Implementation of the planned Islamic school culture are concerned with moral guidance for learners that includes prayer congregation, discipline, clean, honest, shake culture, commemorating PHBI, pray, and others

Implementation of the application of Islamic school culture necessarily involve a variety of devices other schools to support this Islamic school cultural program started the new academic year and will be continued in the next year. Efforts in the implementation of principals, viceprincipals, teachers field of study will give motivation to students, providing both moral and material support, commitment and cooperation with all the school is emphasized so that it can be done well.

Supervision is done together as their representatives assist school heads, teachers, homeroom and supervision is done every day, so whatever is obtained from such monitoring will be used as input and changes at the time of evaluation

Evaluations were conducted in SMA Tunas Bangsa Pre-Eminent State Senior High School Of Aceh Barat Daya done by conducting joint coordination meeting of the board of teachers. The evaluation results obtained by the development of students' awareness of Islamic culture in running the school, and also obtained the persistence of students who violate and not yet fully implementing an Islamic school culture in this case will give rewards to the commitment to run, and also provide punishmen for noncompliance with the regulations that have been made. 


\section{REFERENCES}

Adams, C. M., Olsen, J. J., \& Ware, J. K. (2017). The school principal and student learning capacity. Educational Administration Quarterly, 53(4), 556584.

Anderson, L., Ellwood, P., \& Coleman, C. (2017). The impactful academic: Relational management education as an intervention for impact. British Journal of Management, 28(1), 14-28.

Baharuddin, M. (2017). The Influence Of Diploma Background Working Life And Situational Leadership Factor Of Headmaster Toward The Performance Of Head Of State School In Samarinda

. European Journal of Research and Reflection in Educational Sciences Vol, 5(4).

Bairaðauskienë, L. (2017). Headmaster's competencies in management area: evaluating the significance level of managerial competencies in Lithuanian comprehensive schools. European Journal of Multidisciplinary Studies, 2(5), 158-164.

Böhlmark, A., Grönqvist, E., \& Vlachos, J. (2016). The headmaster ritual: The importance of management for school outcomes. The Scandinavian Journal of Economics, 118(4), 912-940.

Bush, T., Bell, L., \& Middlewood, D. (Eds.). (2019). Principles of Educational Leadership \& Management. SAGE Publications Limited.

Cajiao, J., \& Burke, M. J. (2016). How instructional methods influence skill development in management education. Academy of Management Learning \& Education, 15(3), 508-524.

Chan, M. L. (2018). Management education in the People's Republic of China. In Management Issues in China: Volume 1 (pp. 237-257). Routledge.
Dandan, M. M., \& Marques, A. P. (2017). Higher education leadership and gender gap in Jordan. Asian Development Policy Review, 5(3), 131-139.

Griffith, K. G., Jones, K., Howard, E., \& Winship, J. (2017). Rural School Administrators' Perceptions Of Educators' Skills Needed For Effective Inclusion Classrooms. City Meets Country: Educators Working to Solve the Challenges of Special Education, 60, 52. Jamli, N. F. A., \& Salim, S. S. S. (2019). Development of an Instrument to Evaluate Emotional Intelligence and Leadership Style of Headmasters across Primary Schools in Malaysia. International Journal Of Academic Research In Business And Social Sciences, 9(7).

Kairys, M. R. (2018). The influence of gender on leadership in education management. International Journal of Educational Management.

Kempa, R., Ulorlo, M., \& Wenno, I. H. (2017). Effectiveness Leadership of Principal. International Journal of Evaluation and Research in Education, 6(4), 306-311.

Meyers, C. V., \& Hambrick Hitt, D. (2017). School turnaround principals: What does initial research literature suggest they are doing to be successful?. Journal of Education for Students Placed at Risk (JESPAR), 22(1), 38-56.

Mohammed, K., Alotibie, B. A., \& Abdulaziz, A. (2016). Total quality management in Saudi higher education. International Journal of Computer Applications, 135(4), 6-12.

Ololube, N. P., Agbor, C. N., \& Agabi, C. O. (2017). Effective leadership and management in universities through quality management models. In Innovation and Shifting Perspectives in Management Education (pp. 224-245). IGI Global. 
Serdyukov, P. (2017). Innovation in education: what works, what doesn't, and what to do about it?. Journal of Research in Innovative Teaching \& Learning.

Wong, A. Y., \& Daud, K. (2017). Headmaster Technology Leadership in Malaysia Elementary Schools. Journal of Education and Learning, 11(2), 154-164.

Yieng, W.A., \& Daud, K. B. (2017). Technology leadership in Malaysia's high performance school. Journal of Education and eLearning Research, 4(1), 8-14.

Zuilkowski, S. S., Piper, B., Ong'ele, S., \& Kiminza, O. (2018). Parents, quality, and school choice: why parents in Nairobi choose low-cost private schools over public schools in Kenya's free primary education era. Oxford Review of Education, 44(2), 258-274. 